\title{
Can large-scale land acquisition deals improve livelihoods and lift people out of poverty in sub-Saharan Africa? Empirical evidence from Tanzania
}

\author{
Ernest Nkansah-Dwamena* \\ Arizona State University
}

Submitted February 21, 2020 / Revised June 11 and December 27, 2020, and February 7, 2021 /

Accepted February 8, 2021 / Published online June 8, 2021

Citation: Nkansah-Dwamena, E. (2021). Can large-scale land acquisition deals improve livelihoods and lift people out of poverty in sub-Saharan Africa? Empirical evidence from Tanzania. Journal of Agriculture, Food Systems, and Community Development, 10(3), 243-264. https://doi.org/10.5304/jafscd.2021.103.013

Copyright (C) 2021 by the Author. Published by the Lyson Center for Civic Agriculture and Food Systems. Open access under CC-BY license.

\begin{abstract}
The recent wave of large-scale land acquisitions or land deals, popularly called 'land grabbing' in subSaharan Africa, has provoked vigorous debate over the potential benefits and risks to local people, with results structured by complex policy and institutional context. Land deals present new development challenges and aggravate old vulnerabilities, raising critical questions for investigation. Yet empirical evidence of impacts on local populations is limited, particularly regarding how land deals affect local people's livelihood assets, strategies, and outcomes. Guided by the sustainable livelihood approach and a quasi-experimental design, I compare livelihoods before and after a land deal project and between an affected and a
\end{abstract}

* Ernest Nkansah-Dwamena, Center for Biology and Society (CBS) and the School of Life Sciences (SOLS) at Arizona State University (ASU).

Nkansah-Dwamena, Ph.D., is now Assistant Professor in the Open Academy at SUNY College of Environmental Science and Forestry (ESF); 235-1 Gateway Center, 1 Forestry Drive; Syracuse, NY 13210 USA; +1-315-470-6881; enkansah@esf.edu or ernest.nd@gmail.com control community in southwestern Tanzania. I use household surveys, focused group discussions, and key informant interviews to collect data. The ANOVA analyses revealed that the project severely deteriorated households' natural, financial, and social capital and had far-reaching impacts on wellbeing in the affected community compared to the control village. The study recommends that African countries should consider (1) scrutinizing land deals and enforcing contracts, (2) conducting rigorous environmental and social impact assessment, (3) strengthening customary land rights and reinforcing compensation policies, and (4) meaningfully involving locals in land deal negotiations. This contribution responds to the deficit in research on land deals' impacts on livelihoods and well-being and lays the groundwork for future research.

\section{Funding Disclosure}

This research was carried out as part of a Ph.D. supported by the Center for Biology and Society (CBS) and the School of Life Sciences (SOLS) at Arizona State University (ASU). The support of both the Center and the School is gratefully acknowledged. 


\section{Keywords}

Large-Scale Land Acquisition, Land Grabbing, Livelihoods, Sustainable Livelihood Approach, Tanzania, Sub-Saharan Africa, Kilombero Plantation Limited, Agricultural Investment

\section{Introduction}

Since 2007, a convergence of global crises in food, fuel, and finances have driven multinational corporations (MNCs), sovereign wealth funds, and private investors from the Global North to acquire large tracts of farmland in the Global South. This acquisition usually entails a transfer of rights to use, control, purchase, or lease land. The land size varies but typically ranges from 200 to several thousands of hectares (ha) in a single deal (Land Matrix, 2020). This practice, called large-scale land acquisition (LaSLA), has sparked a debate that has become increasingly contentious among the media, academics, policymakers, and human rights organizations. The debate revolves around LaSLA's impacts on local people's development and wellbeing across sub-Saharan Africa (SSA) (NkansahDwamena \& Raschke, 2020). This region accounts for approximately $70 \%$ of global land acquisitions (Anseeuw et al., 2012). With 754 LaSLA deals equivalent to about 56.2 million hectares, SSA has become an attractive destination due to available water and fertile land (Land Matrix, 2020).

The recent scale and intensity of LaSLA are unprecedented, and the exact extent of land under investment remains a matter of discussion (Hajjar et al., 2020). Scholars and the media often use terms as 'land grabbing,' 'commercial pressures on land,' 'land rush,' and 'new enclosures' to describe LaSLA (Anseeuw et al., 2012; Tafon \& Saunders, 2019; White et al., 2012). These terms depict the fast pace of land deals, their highly contested nature, and the continuous struggles of local people who depend on land for their livelihood (Dell'Angelo et al., 2017; Zoomers et al., 2017). Approximately $78 \%$ of LaSLA investors produce food, biofuels, and other agricultural commodities for export to their home countries to meet growing demands or to the international market for profit (Byerlee \& Deininger, 2013; Cotula, 2012). Usually, land acquisitions happen through negotiations with the host government. However, in some countries, the investor deals directly with local landowners. Access to water is critical for LaSLA projects; thus, investors often seek water rights (Breu et al., 2016; D'Odorico et al., 2017). Investors' scramble for water and land raises an essential question about how these projects affect local people's access to natural capital, particularly land and water, for their livelihoods.

\section{Is LaSLA a Development Opportunity or a Threat to Development?}

In the following section, I discuss the debate on LaSLA to contextualize the need for more empirical studies to improve our understanding of LaSLAs' impacts on local communities and reveal the apparent weaknesses in structuring LaSLA deals. By offering a more holistic discussion about the opportunities and threats of LaSLA, I hope to contribute a clearer picture of the procedural and distributive problems associated with the phenomenon. Such a discussion is also vital because the results of LaSLA projects are context-specific and provide insights into local people's experiences in SSA host countries.

LaSLA has attracted considerable attention in global development circles because there are significant benefits and severe impacts of the practice. Two competing narratives shape the current LaSLA debate. On the one hand, we can consider LaSLA, if done right, as a 'win-win' deal where investors secure land for production and host countries reap development benefits. Proponents claim that introducing foreign capital and transferring technology will modernize agriculture and improve local livelihoods (Salverda, 2019). Such structural transformation through the commercialization of subsistence farming is critical, the argument goes, to enhancing food security in countries like Ethiopia and Kenya (Baumgartner et al., 2015; Hajjar et al., 2020).

LaSLA can also enhance a nation's gross domestic product (GDP), diversify rural economies, and help reduce poverty by providing loans and employment for households (Li, 2011; Sulle, 2017). Advocates highlight the vital role of LaSLA projects in tying together land, labor, and capital, especially in countries with dwindling official development assistance (Baumgartner et al., 2015; Byerlee 
et al., 2011). They claim that LaSLA generates positive spillovers by improving human capital through capacity building and training local farmers (D'Odorico et al., 2017). For countries like Uganda and Mozambique, LaSLA provides an opportunity for global market integration and improved infrastructure such as machinery, roads, and irrigation systems (Byerlee et al., 2011). This study examines whether these potential benefits are occurring in the case study communities in Tanzania.

LaSLA critics, on the other hand, argue that governments and investors ignore local populations' diverse land values when making LaSLA arrangements (Tafon \& Saunders, 2019). In many cases, LaSLA has led to the loss of livelihoods due to displacement of smallholders (Gironde \& Golay, 2015), decline in income (Shete \& Rutten, 2015), food insecurity (Atuoye et al., 2021) and competition for land and water between investors and locals (Breu et al., 2016). The competition for resources further leads to social upheaval and violence, especially in countries with weak governance like Madagascar and Ethiopia (Mollett, 2016). In SSA, access to land is indispensable to people's livelihoods. Land is a source of identity and belonging. It is often their most significant asset and is a safety net even for those who do not depend directly on the land for livelihood. In Ethiopia, LaSLA has dispossessed smallholders and pushed them into labor markets (Regassa et al., 2019). Thus, it has increased unemployment, creating conditions in which investors continuously exploit cheap labor (Shete \& Rutten, 2015), bring workers from their home countries (Gingembre, 2015), and create seasonal jobs (Hajjar et al., 2020; Li, 2011).

Previous research indicates that LaSLA weakens tenure security and reduces local people's access to resources for livelihood (Breu et al., 2016; Gironde \& Golay, 2015). Moreover, studies show examples of LaSLA practitioners excluding locals from consultation and LaSLA negotiation processes (Nolte \& Voget-Kleschin, 2014). Governments and investors have occasionally realized the need to involve locals in LaSLA processes and pledged to adhere to international guidelines on land acquisitions such as USAID's Operational Guidelines for Responsible Land-Based Investment and the FAO's Voluntary Guidelines on the Responsible
Governance of Tenure of Land, Fisheries, and Forests in the Context of National Food Security (VGGT), and other relevant instruments, like the United Nations' Guiding Principles on Business and Human Rights (UNGP). Nonetheless, such promises are all too rare (Salverda, 2019), and governments infrequently involve affected people in decision-making or compensation negotiations for displacement. They also ignore the principle of free, prior, and informed consent (FPIC). Because of these grave threats to local communities, Liberti (2013) argues that LaSLA is ruthless exploitation of the poor and reminiscent of colonialism.

The ongoing discussion here shows that LaSLA is a double-edged sword with both positive and negative effects. Despite these realities, our understanding of how the local political economy determines the winners and losers of LaSLA projects in Tanzania is limited. This paper contributes to this debate by examining the structures and processes that influence households' vulnerability context (e.g., displacement, unemployment, food insecurity, and loss of livelihood) in rural Tanzania. Knowledge of these nuances can offer insights on policy relating to the design of LaSLA investments. Thus, this study focuses on how LaSLA affects local people's access to the various capital assets needed for household well-being. In so doing, it responds to calls for more empirical work on the benefits and risks associated with LaSLA.

Although there is research on the socioeconomic impacts of LaSLA on contract farmers in Tanzania (Pedersen, 2016; Sulle, 2017), the literature has yet to offer a comprehensive analysis of LaSLA's effects on the five livelihood assets while taking into consideration livelihoods before and after LaSLA. My objective is to analyze the impacts of the Kilombero Plantation Limited (KPL) LaSLA project in southwestern Tanzania on these five livelihood assets. In other words, I rely on the SLA to examine whether and how LaSLA processes and structures (e.g., investors and governments) affect households' livelihood assets, strategies, and outcomes. By examining LaSLA's impacts on livelihoods in Mkangawalo (affected village) and comparing it with livelihoods in Chita (control village) using a pretest-posttest approach, I hope to tease out determinants of livelihood outcomes. 
The Sustainable Livelihood Approach (SLA) I adopt the sustainable livelihoods approach (SLA) (Figure 1) to evaluate LaSLA's impacts on households' livelihood assets, strategies, and outcomes in the study area. The SLA developed by the Department for International Development (DfID, 1999) is relevant for this study because it provides an analytical approach to explore LaSLA's impacts on households' livelihoods. The study employs the SLA to understand how household livelihood systems interact with the external environment-both the natural environment and the policy and institutional context. Relying on the earlier definition by Chambers and Conway (1992) and further developed by Scoones (1998), we can define a livelihood as "compris[ing] the capabilities, assets (including both material and social resources) and activities required for a means of living. A livelihood is sustainable when it can cope with and recover from stresses and shocks, [and] maintain or enhance its capabilities and assets, while not undermining the natural resource base" (p. 5). According to Chambers (2011), it is "a level of wealth and of stocks and flows of food and cash which provide for physical and social wellbeing" (p. 5). A sustainable livelihood provides security against pov- erty and ensures the well-being of households. For rural people, "well-being" may mean just the ability to provide adequate food, shelter, and security for household members. For others, standards may be higher, but whatever the definition, a livelihood is primarily the means to achieve and sustain wellbeing (Messer \& Townsley, 2003).

\section{Components of the Sustainable Livelihood Approach}

Five concepts are crucial for understanding the linkages within the SLA framework. These are the vulnerability context, livelihood assets, institutions, livelihood strategies, and livelihood outcomes.

Regarding the vulnerability context, many factors which households may have little or no control over can affect their access to adequate livelihood assets. These factors can include weather-related shocks (drought and floods, pest and disease epidemics), economic shocks (drastic changes in market prices affecting households' purchasing power), seasonal stress (famine and food insecurity), environmental stress (land degradation, soil erosion, and bush fires), structural vulnerability (lack of voice or power to make claims), and civil strife (displacement and destruction of property) (Messer \& Townsley, 2003). These events and forces can

\section{Figure 1. The Sustainable Livelihood Analysis (SLA) Framework, Adapted from the Department for International Development}

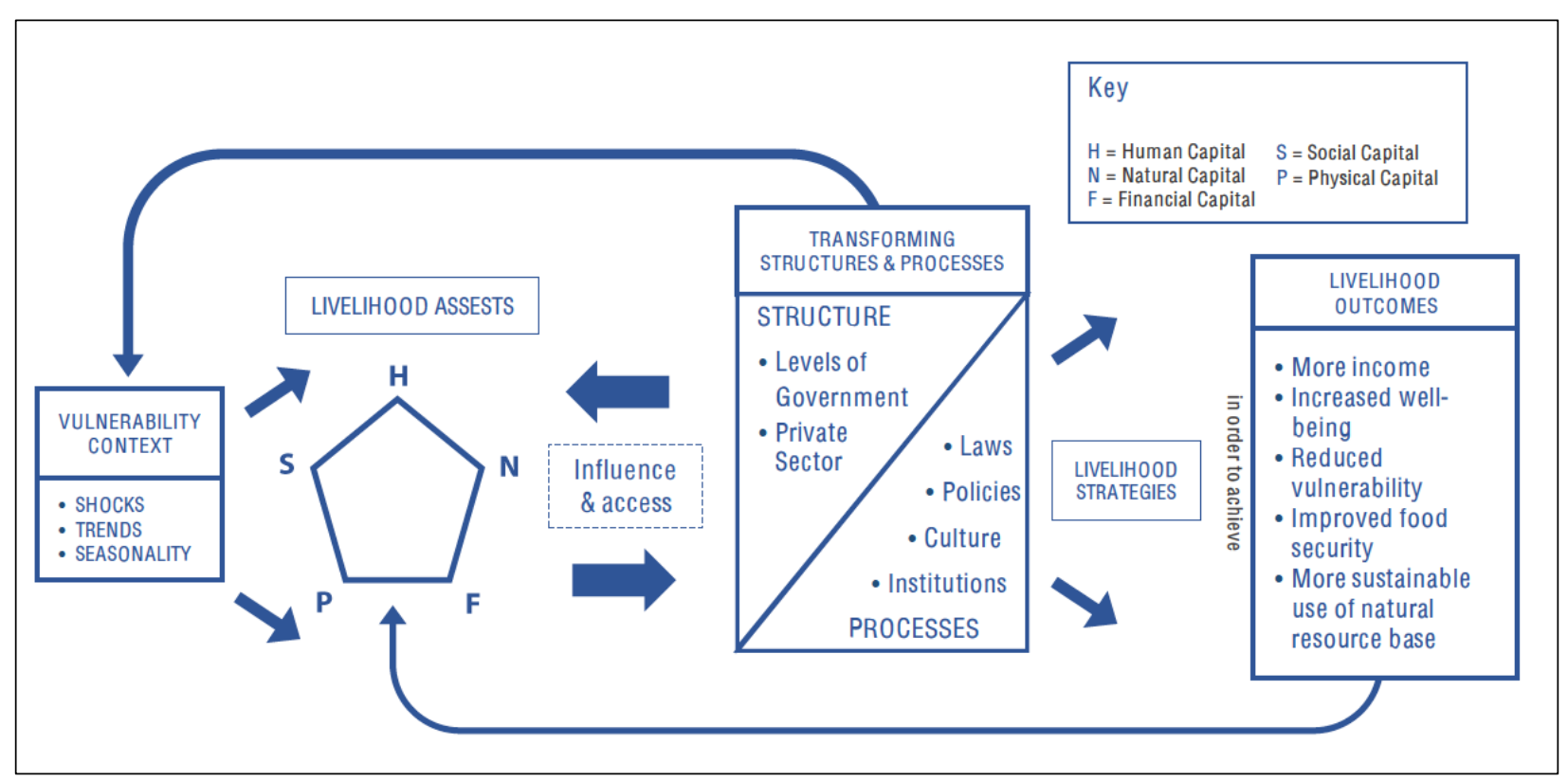

Source: Department for International Development (DfID). (1999). Sustainable livelihoods guidance sheets: Overview, 1.1, p. 1. 
undermine livelihoods and potentially make households more vulnerable to poverty. For example, inadequate or lack of access to land, water, or social support due to displacement by LaSLA could make households vulnerable to shocks that contribute to adverse livelihood outcomes, an underlying condition for poverty. It is worth noting that policies, institutions, and processes that do not support households in achieving an adequate livelihood can also cause poverty. We can think of these many factors as contributing to the vulnerability context in which households operate, affecting how people use their assets and strategies. For example, where governments displace smallholders to make way for LaSLA projects, smallholders may choose to work as casual laborers or contract farmers for the investor.

\section{Livelihood Assets (Capital) and Strategies}

Livelihood assets include social, financial, human, natural, and physical capital. These assets are critical for individuals, households, and communities to pursue their livelihood strategies, which enable them to achieve their desired goals or livelihood outcomes (e.g., reduced vulnerability, more income, improved health, and food security). The ability of household members to work together and with the broader community is vital to their livelihoods. However, national and local policies, institutions, and processes also influence livelihood assets.

In rural areas, households are connected by ties of social obligation and mutual support, which are especially crucial during emergencies. We can consider these as social capitals that constitute a household's livelihood capabilities. Thus, social capital encompasses the norms of reciprocity, mutual trust, social networks, and relationships that support individuals (Bourdieu et al., 2019). Putman (1993) refers to it as the "feature of social organization that facilitates coordination and cooperation for mutual benefit" (pp. 35-36). The financial capital at rural people's disposal may originate from converting surplus harvest for money to save for an emergency or invest in other activities. It includes cash, credit, gold and jewelry, bank deposits, loans, income, and savings (Scoones, 1998). In rural areas, households use their financial capital to establish businesses or shield against stresses and shocks.

People's active labor, health, education, training and skills, leadership qualities, and the knowledge they have gained over generations of experience that enable them to earn a living constitute their buman capital (Flora et al., 2016). In rural households, human capital determines the quantity and quality of available labor or the workforce and is also needed to leverage and enhance other capitals. Natural capital refers to stocks of naturally occurring environmental resources such as land, fresh water, forest, pasture, and wildlife that directly or indirectly support people's livelihoods (Scoones, 1998). For rural people, these assets are essential for producing food, shelter, and income. How households access these resourcesownership, lease, communal land, etc.- - and for how long and under what conditions are all crucial considerations in determining livelihood outcomes, in addition to the condition of the resources themselves. Finally, physical capital includes the infrastructure, facilities, services, and structures that support society, including roads, buildings, vehicles, equipment, communication technologies, irrigation, health care, and energy (Flora et al., 2016). These also enable households to improve their human capital.

People exploit the livelihood assets described above to pursue livelihood strategies-combining different activities and choices to achieve their livelihood goals or outcomes. These strategies include how households combine their revenue-generating activities, such as using, investing, or preserving their assets. For example, rural households might grow a mix of staple and cash crops, raise livestock, fish, and gather forest products to meet their food and nutritional needs, combined with the sale of farm harvest surpluses on the local market. Depending on their individual goals, knowledge of assets, and options available, households may pursue distinct livelihood strategies.

\section{Policy and Institutional Context}

The policy and institutional context in which households live also influences their access to livelihood assets, their vulnerability context, and their livelihood strategies. It involves how institutions shape the different livelihood assets available 
to households, by controlling access to resources or influencing how, where, when, and who uses them (Scoones, 2015). For instance, when governments implement agriculture investment policies like LaSLA projects, it may lead to loss of access to land (livelihood asset) and displacement (vulnerability context) and consequently may cause people to migrate (livelihood strategy) in search of alternative livelihoods. The term "institution" refers to various formal and informal organizations (structures), policies, and processes (arrangements) at national and local levels that determine the amount of assets and how households use their assets (Scoones, 2015). Formal or visible institutions are structures of recognized and accepted roles with clearly defined rules and regulations; informal or invisible institutions are unstructured and have no written statutes. Example of institutions include:

1. government agencies that implement and enforce rules and regulations, and protect the peoples' rights;

2. political groups that act on behalf of certain groups or people and effect new laws and policies;

3. investors, entities, and corporations with capital that employ people and produce goods and services; and

4. social-cultural institutions such as kinship, marriage, inheritance, and religion.

One can assume that households that are members of or have better access to these institutions potentially have better access than others to the services the institutions provide, the assets they control, or the rights they protect. At the local level, institutions may affect household livelihood strategies by deciding whether certain activities are suitable for women and men, incentivizing the pursuit of specific livelihoods and choices over others, and influencing a household's perception of achieving desired goals. Where an enabling policy and institutional context (e.g., one that is democratic and accountable) enhances households' access to livelihood assets, a disabling context (e.g., one that is elite-dominated and less transparent) disfavors the poor and worsens their access to the resources needed to escape poverty.
Different government levels decide and enact policies that shape household decision-making and the use of their assets. For instance, policies that place more autonomy and authority in village leaders' hands may provide locals more power and influence over the decisions and actions affecting them directly. Similarly, environmental protection and conservation policies that take full control of a given natural resource can make it more difficult for households to access the resources they usually rely on to supplement their livelihoods. Equally important to the policy is the policy formulation processes. For example, failure to consult and involve locals in the mechanisms that lead to policy formulation implies that the locals will have no means of influencing the policies that might affect them directly. Thus, they are more likely to be adversely affected by those policies.

\section{Livelihood Outcomes}

Livelihood outcomes can be positive or negative. They are what households achieve through their livelihood strategies, such as food security levels, income security, health, well-being, asset accumulation, and high status in the community (Scoones, 2015). For example, suppose LaSLA results in food and income insecurity, increased vulnerability to shocks, displacement, and loss of access to assets; in that case, we can consider these as unsuccessful outcomes. With adequate access to livelihood assets, reduced vulnerability, and the right policies, institutions, and processes, households are more likely to develop appropriate livelihood strategies, leading to better livelihood outcomes (Messer \& Townsley, 2003). Livelihood outcomes, in turn, may improve or deteriorate livelihood assets. The vulnerability context (e.g., households' encounters with unexpected shocks) affects their livelihood outcomes, depending on their livelihood assets.

In this study, I apply the SLA to explore the relevant channels of asset distribution and the roles of various LaSLA actors, including the investor, Tanzanian government (hereafter GoT), and NGOs, in shaping livelihood outcomes. These actors and LaSLA policies and processes control, distribute, and transform households' livelihood assets and strategies. Although the SLA framework is relevant for identifying and evaluating the effects 
of development projects such as LaSLA on poverty reduction (Chambers, 2011), it fails to address power relations. Nevertheless, similar to Scoones (2015), I argue that it provides a critical and comprehensive approach for analyzing a complex issue like LaSLA. The SLA framework puts "people" first and enables us to understand complex local realities. In the next section, I provide a brief background of Tanzania's LaSLA development and describe the LaSLA project.

\section{Background: LaSLA Development in Tanzania and Study Villages and LaSLA Project}

I rely on in-depth case studies in two communities in southwestern Tanzania to investigate the consequences to livelihoods of LaSLA. Tanzania is a well-suited area in which to study these issues. Additionally, it was logistically convenient to collaborate with agriculture investment experts at the Sokoine University of Agriculture. With only 23\% (10.2 million ha) of Tanzania's land under cultivation, land is considered underutilized (Sulle $\&$ Nelson, 2009). Thus, Tanzania is regarded as one of the top LaSLA target countries in SSA (Anseeuw et al., 2013). The GoT, keen to transform small-scale farming into commercial pro- duction, has established new initiatives, including the Kilimo Kwanza (meaning 'agriculture first'), to attract foreign investors. GoT's efforts to extend state authority and tighten control over land afford it a unique opportunity to negotiate with investors and transfer control over massive tracts of land. Renewing its interest in foreign investments, the GoT established the Tanzania Investment Act of 1997. It also formed the Tanzania Investment Centre (TIC), a 'one-stop agency' that streamlines LaSLA investment procedures and provides tax holidays for investors. Figure 2 shows the trend of LaSLA deals in Tanzania over the last two decades. One such capital-intensive farm is the Kilombero Plantation Limited (KPL) LaSLA project, the case study for this research. Studies on recent LaSLA in Tanzania show similar adverse livelihood outcomes for local communities as described across SSA (Atuoye et al., 2021), making a study of LaSLA's impacts on livelihoods in Tanzania all the more relevant and urgent.

This study's spatial focus is Kilombero Valley of Morogoro Region (Figure 3), a district that has seen high demand for LaSLA since the early 1990s. Kilombero, with approximately 392,600 hectares of land (Tanzania National Bureau of Statistics, 2018), is one of Tanzania's largest rice-producing areas.

Figure 2. The Number of LaSLA Deals and Land Size Acquired by Investors Between 2000 to 2015 in Tanzania Registered by the Tanzania Investment Centre

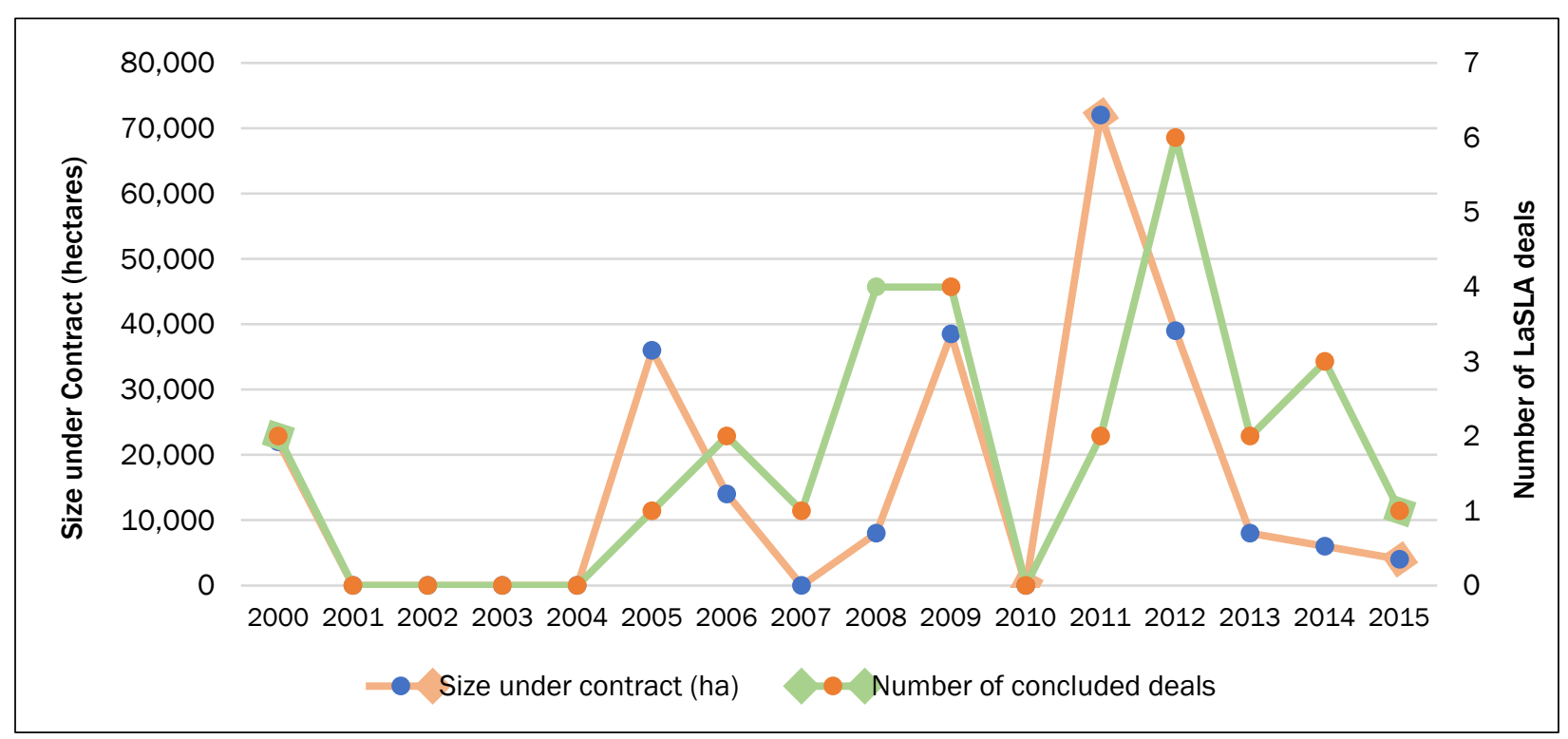

Data source: The Land Matrix (2020). 
With 5,818 hectares of land, the KPL, located in the Mchombe Ward of the Mngeta Division, is among the top commercial rice producers in Tanzania. Because it has operated for nearly two decades, its impacts on livelihoods are visible, making it suitable for the study. The project is a joint venture rice plantation between the Rufiji Basin Development Authority (RUBADA), which owns 8.7\%, and Agrica Guernsey Limited, a United Kingdom private firm, which owns $91.3 \%$. The firm aims to create employment for local people, connect farmers to market, and improve exports in Tanzania. The investor operates a plantation farm and a nucleus estate (outgrower model), which operates through contract farming to produce rice for export and the domestic market.

\section{Methods}

\section{Study Design}

This study uses a pretest-posttest and quasi-design to explore the differences and similarities between the treatment and control village to understand the LaSLA's impacts (Chan et al., 1998; Dimitrov \& Rumrill, 2003). This understanding then provides a basis for conjecturing about LaSLA's implications in similar local settings in Tanzania and SSA. A case study methodology allows insights into people's real-life and contextual experiences to uncover the deeper meaning of LaSLA (Yin, 2017).

I conducted fieldwork in two rounds of visits to the study sites—preliminary studies in May 2014 and field studies in June 2015. After interviewing

\section{Figure 3. Map of Tanzania Showing the Study's Location (Mkangawalo Village) and Control Site (Chita Village) in the Kilombero District of Morogoro Region}

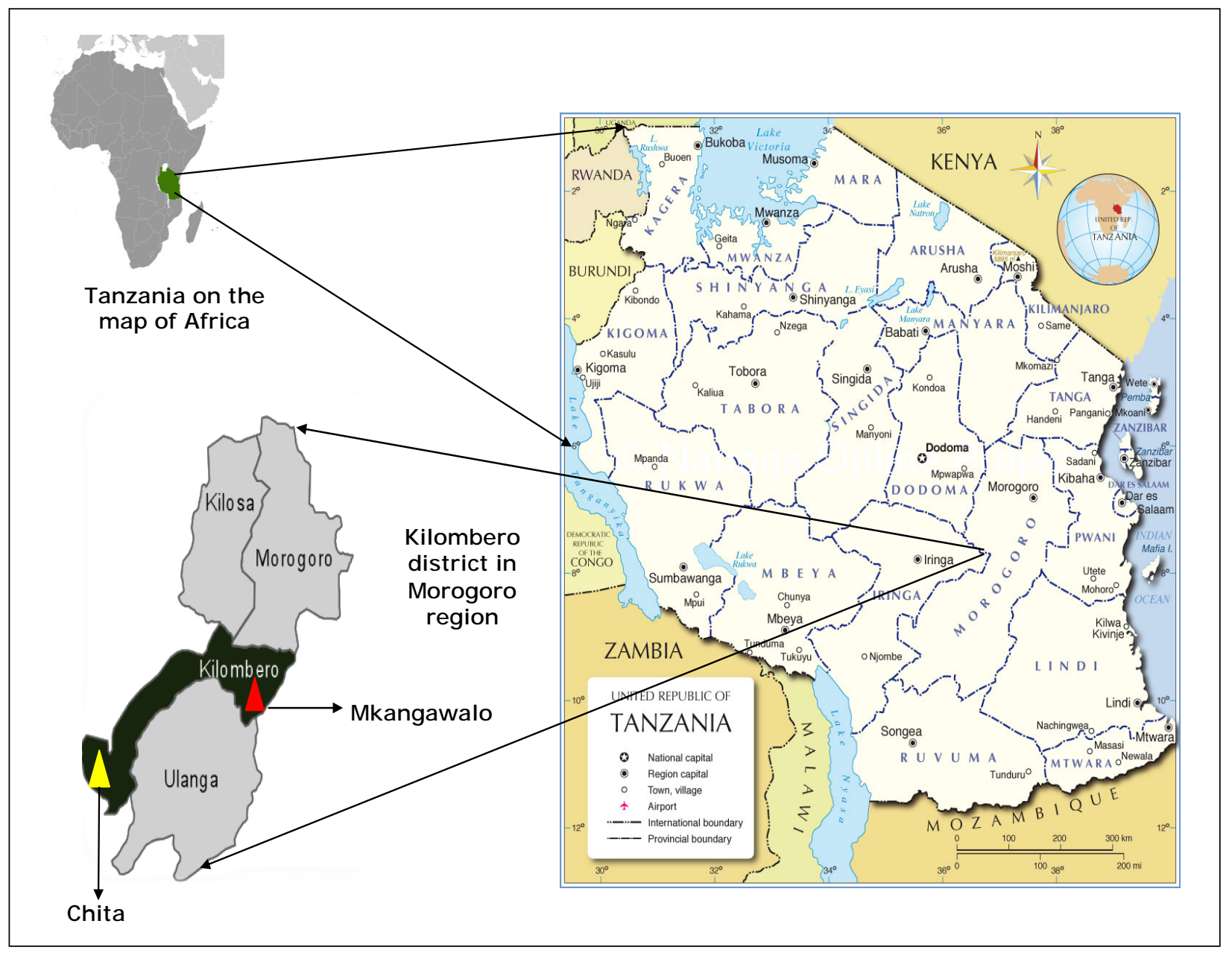


key informants during the pilot studies in eight villages, I selected Mkangawalo as the case study community (the "treatment" village) in the Kilombero District (Figure 3). My goal was to choose a village with strong ties to the LaSLA project to examine the impacts on households' livelihoods. Mkangawalo shares borders with the project, and some residents work as contract farmers for the investor. I also selected a "quasi-control" community, Chita, where no LaSLA had occurred; this community is part of Kilombero, is further away from the KPL LaSLA project, and was less affected or unaffected by the project. The fact that Chita had a similar socio-economic profile and contextual factors as Mkangawalo helps to tease out the LaSLA's impacts on Mkangawalo. I used

Table 1. Demographic and Household Characteristics of Respondents in the Study Area $(n=200)$

\begin{tabular}{|c|c|c|}
\hline & \multicolumn{2}{|c|}{ Kilombero District } \\
\hline & Mkangawalo Village & Chita Village \\
\hline Average yearly income (USD) & $\$ 2,342$ & $\$ 2,533$ \\
\hline Average age of respondent & 54 & 42 \\
\hline Average household size & 5.2 & 5.6 \\
\hline Average land holdings (ha) & 1.4 & 2.2 \\
\hline Average years of residence & 42 & 27 \\
\hline \multicolumn{3}{|l|}{ Gender } \\
\hline Male & 58 & 49 \\
\hline Female & 42 & 51 \\
\hline \multicolumn{3}{|l|}{ Marital status } \\
\hline Married & 45 & 56 \\
\hline Single & 55 & 44 \\
\hline \multicolumn{3}{|l|}{ Household status } \\
\hline Head & 66 & 62 \\
\hline Wife/Member & 34 & 38 \\
\hline \multicolumn{3}{|l|}{ Years of formal education } \\
\hline None & 4 & 3 \\
\hline $0-5$ years & 89 & 91 \\
\hline $6-10$ years & 7 & 6 \\
\hline $11-15$ years & 0 & 0 \\
\hline $16-20$ years & 0 & 0 \\
\hline \multicolumn{3}{|l|}{ Farming as livelihood } \\
\hline Before & 47 & 45 \\
\hline After & 53 & 55 \\
\hline \multicolumn{3}{|l|}{ Main farm crops } \\
\hline Rice & 91 & 85 \\
\hline Maize & 9 & 15 \\
\hline
\end{tabular}

information from Chita to compare livelihood outcomes that occurred in Mkangawalo, the affected community. Households in both areas are mainly smallholder rice and maize producers. The study areas' predominant ethnic groups are WaBena, WaNgoni, WaChagga, WaSukuma, WaNdamba, and WaPogoro.

\section{Data Collection}

I collected data primarily through household surveys, focus group discussions (FGDs), and key informant interviews. In the household survey, I used structured and semi-structured interviews to solicit households' perceptions of impacts on their livelihoods. I pretested the questionnaires and checked for coherency and comprehension and made the necessary modifications. Cronbach's alpha, a test of scale reliability and internal consistency in the questionnaire, was determined to be high, i.e., 0.7452 (Gliem \& Gliem, 2003). The interviews involved a one-to-one in-depth discussion with respondents. Overall, I interviewed 200 households $(n=200), 100$ in each village. I selected households using stratified random sampling to increase statistical representation and reliability and reduce sampling bias. I grouped households into different strata based on religion, hamlet division, ethnicity, and wealth status.

The interviews solicited the households' demographic information (Table 1) and their perceptions of changes in access to livelihood assets and how these changes affect their livelihood strategies and outcomes. The livelihood assets inquired about included natural capital (land, water, forest, and pasture); financial capital (savings, loans, and farm and off-farm income); human capital (health, education, training, and skills); social capital (trust, relationships, networks, and external services); and physical capital (irrigation schemes, clinics, roads, and farm inputs). After each interview, I summarized the responses and asked the interviewee to affirm whether the summaries reflected their views, feelings, and experiences. 
For each village, I conducted separate FGDs with men, women, and youth from 21 to 31 years old, drawing on participants' collective experiences and beliefs moderated by a team of skilled facilitators. I further separated the youth group by gender. All FGDs consisted of eight participants except the youth group (four young men and four young women). The village leaders and ward officers (lower administrative unit) assisted in selecting FGD participants to diversify the group along various axes: religion, employment with the investor, ethnicity, hamlet location, and wealth status. For the women's groups, I also ensured the representation of widows and female-headed households. I acknowledge that relying on the local authorities to select the FGD participants potentially may have introduced a sampling bias. Nonetheless, this sampling method was the most efficient and practical because of the local culture and time constraints.

The FGDs started with a participatory mapping exercise. The villagers worked together to sketch the village's key physical features, including the sacred areas, forests, rivers, and boundaries of the LaSLA project concerning their farmland. In the process, the groups deliberated over their relationship with the investor and shared their observations and personal stories about land tenure changes, displacement, compensations, and contract farming. I used the mapping exercise to start a dialogue about livelihood assets, strategies, and outcomes before and after the LaSLA project. The discussions occurred in multiple sessions until reaching theoretical saturation, where a clear pattern emerged and subsequent sessions produced no new information. The FGDs facilitators created a conducive environment to engage in an open discussion, free from individual dominance and influence. The FGDs lasted 2-3 hours, and they were instrumental in exploring the village's legitimization and level of support for the LaSLA project.

I also conducted key informant interviews with five informants from the study area, including the investor's representative, an officer from HAKIARDHI (a local NGO), an officer from the Tanzania Investment Center (TIC), village leaders, and an agricultural development expert from the Sokoine University of Agriculture. Each interview lasted 2-3 hours and focused on understanding the LaSLA implementation process, the government's role and/or support, investor's responsibilities, changes in access to natural resources, the project's benefits and risks, and livelihood strategies before and after the LaSLA project.

\section{Data Analysis}

I collected data on LaSLA's impacts on a household's (as a unit of analysis) livelihoods. Impacts were measured by determining the changes in livelihood assets, which refer to increase or decrease, comparing before (2005) and after (2015). I recorded the changes on a 5 -point numerical rating scale, where 5 represents much better (50\% more), and 1 represents much worse (50\% less). The quantitative data were statistically analyzed in two steps using Minitab Statistical Software.

The first step involved multiple pairwise comparisons using one-way ANOVA (with Tukey test) to determine whether and how the means (averages) of livelihood assets between Mkangawalo and Chita are significantly different. In other words, I compared the changes in livelihood assetsmeasured by the difference between before and after LaSLA and between the treatment and control village. Using averages can hide the disparities in the data and give a misleading result; however, the data had no dispersions. Thus, it was safe to use averages for comparison. The statistical significance of the difference was set at $p<0.05$. For comparison of livelihood assets between the villages, if Mkangawalo and Chita share the same letter (see table 2), they belong to the same group, or their asset did not change. Thus, we can say that LaSLA did not affect that particular asset in Mkangawalo. However, if the villages show different letters, it indicates changes in livelihood assets between Mkangawalo and Chita as an impact of LaSLA.

The second step involved calculating a percent change to evaluate the changes' significance (i.e., better or worse) in livelihood assets between the villages. A positive change represents an improvement, while a negative change represents a deterioration in livelihood. All assumptions underlying the one-way ANOVA were satisfied. The demographic data provided an aggregate picture of the 
villages, including information about their human capital (household size and education level), financial capital (income), natural capital (land holdings), and social capital (years of residence). It also provided insights on households' livelihood strategies, food security, and knowledge of the LaSLA project.

The qualitative data were analyzed using content and ethnographic techniques. I audio-recorded and transcribed the FGDs, household interviews, and key informant interviews, after which I coded the data in two stages after transcription. I initially coded and re-arranged the transcripts into themes based on livelihood assets and emergent codes such as livelihood strategies and outcomes. This enabled comparisons between the treatment and control village. As much as possible, I tried to triangulate information from the household interviews with the FGDs, key informant interviews, and available documentation.

In the second stage, I used focused coding to eliminate, merge, and categorize the codes identified in the first step to concentrate on recurring ideas and broader themes connecting the codes (O.Nyumba et al., 2018). This allowed for comparisons between groups. I sought to examine all the evidence and significant rival interpretations, particularly regarding the critical issues of the case study (Yin, 2017). I interpreted the results by assessing and comparing the data with similar studies done in Tanzania and other parts of SSA. In the next section, I present the results (Table 2), highlighting the changes in households' livelihood assets associated with the LaSLA project and how these changes have caused livelihood strategies within households to shift. Finally, I present the consequences and well-being resulting from the project.

Table 2. Changes in Livelihood Assets, Comparing Affected Village (Mkangawalo) and Control Village (Chita) Before and After LaSLA Project in the Kilombero District ( $n=100)$

\begin{tabular}{|c|c|c|c|c|c|c|c|c|c|}
\hline \multirow[b]{2}{*}{ Type of Capital } & \multirow[b]{2}{*}{ Livelihood Asset } & \multicolumn{3}{|c|}{ Mkangawalo } & \multicolumn{3}{|c|}{ Chita } & \multirow[b]{2}{*}{$p$} & \multirow[b]{2}{*}{$\begin{array}{l}\text { Percent } \\
\text { change }\end{array}$} \\
\hline & & Mean & SD & Group & Mean & SD & Group & & \\
\hline \multirow[t]{4}{*}{ Natural capital } & Access to land & 2.00 & 1.36 & B & 3.08 & 1.07 & $A$ & 0.000 & -35.06 \\
\hline & Access to water & 2.04 & 0.88 & $\mathrm{~B}$ & 2.46 & 1.07 & $A$ & 0.035 & -17.07 \\
\hline & Access to forest & 1.44 & 0.67 & $\mathrm{~B}$ & 2.42 & 1.18 & $A$ & 0.000 & -40.50 \\
\hline & Access to pasture & 1.50 & 0.89 & B & 2.58 & 0.95 & $A$ & 0.000 & -41.86 \\
\hline \multirow[t]{4}{*}{ Financial capital } & Savings & 2.48 & 1.25 & A & 2.70 & 1.22 & A & 0.374 & -8.15 \\
\hline & Access to loans & 2.50 & 1.02 & $A$ & 2.20 & 1.11 & $A$ & 0.161 & +13.64 \\
\hline & Average farm income & 2.68 & 1.02 & $\mathrm{~B}$ & 3.40 & 0.90 & A & 0.000 & -21.18 \\
\hline & Average off-farm income & 3.08 & 1.21 & A & 3.36 & 1.01 & A & 0.211 & -8.33 \\
\hline \multirow[t]{4}{*}{ Human capital } & Health & 3.06 & 1.41 & $A$ & 3.36 & 1.08 & $A$ & 0.235 & -15.00 \\
\hline & Education & 3.18 & 1.30 & $A$ & 3.28 & 1.09 & $A$ & 0.678 & -3.05 \\
\hline & Training & 2.94 & 1.15 & B & 3.34 & 0.63 & $A$ & 0.033 & -11.98 \\
\hline & Skills & 2.22 & 1.11 & A & 2.10 & 1.19 & $A$ & 0.148 & +5.71 \\
\hline \multirow[t]{4}{*}{ Social capital } & Social networks & 2.60 & 0.97 & $\mathrm{~B}$ & 3.56 & 0.73 & $A$ & 0.000 & -26.97 \\
\hline & Trust in people & 2.94 & 1.06 & $\mathrm{~B}$ & 3.68 & 0.74 & $A$ & 0.000 & -20.11 \\
\hline & Relationships & 3.26 & 0.90 & A & 3.60 & 0.88 & A & 0.059 & -9.44 \\
\hline & External service & 2.17 & 1.30 & $A$ & 2.28 & 1.09 & $A$ & 0.678 & -4.82 \\
\hline \multirow[t]{4}{*}{ Physical capital } & Irrigation scheme & 2.40 & 1.01 & A & 2.23 & 1.10 & A & 0.159 & +7.62 \\
\hline & Health clinic & 3.13 & 0.98 & $A$ & 3.04 & 1.09 & $A$ & 0.146 & +2.96 \\
\hline & Road and transport & 2.01 & 0.71 & B & 3.18 & 1.24 & A & 0.000 & -36.79 \\
\hline & Farming inputs & 2.12 & 1.01 & $A$ & 2.08 & 1.14 & $A$ & 0.110 & +1.92 \\
\hline
\end{tabular}




\section{Results} Impacts of the Kilombero Plantation Limited (KPL)
on Livelihoods in the Study Area

\section{Natural capital}

In comparing natural capital between the study village (Mkangawalo) and control village (Chita), the results (Table 2) show that in Mkangawalo, access decreased significantly in all measures of natural capital post-investment. More specifically, households' access to the forest declined by $40 \%$, pasture by $41 \%$, water by $17 \%$, and average land holdings by $35 \%$. The LaSLA project displaced approximately $35 \%$ of Mkangawalo's residents off their farmland, leading them to become dependent on the investor for casual labor. They did not have any land to grow their own crops for food and sale on the market. This worsened their financial security because of the low wages and seasonality of the job. Regarding the displacement, the investor's representative said:

We did not displace any villager. After processing our documents, the government allocated the land to us, and the district authorities helped us claim it. Maybe they were displaced by the officers and not us.

Relocated farming and grazing lands at the village outskirts were generally smaller and infertile following the LaSLA project (decreased from 4-5 ha to 1-1.4 ha). Similar events and trends, like forest conversion and shrinking landholdings, were also happening due to population growth in the control village. However, the key informant interview revealed that the LaSLA project accelerated the affected village's situation. A few households in Chita experienced a decline in landholdings, but over $90 \%$ continued to be larger than in Mkangawalo. According to the FGDs, some households cultivated vegetables along the riverbanks to supplement their farm yield before the project, but the investor cleared the land, destroying their farms. This worsened their food security and made them vulnerable to hunger. The smaller landholdings and crop pests, including rodents from the investor's plantation, resulted in a low crop harvest and crop variety grown for household consumption and sale. Households reported no longer growing crops like wheat, sorghum, millet, and beans but having to buy these products from the market. In contrast, households in Chita reported increasing farm yield and diversity of crops grown and reported consuming more food than in the past decade while buying less food. A key informant from HAKIARDHI commented on the issue of food insecurity in Kilombero, saying:

Food insecurity will continue in villages because there is no clause in the government's LaSLA contract requiring the investor to produce a specific percentage for the local market. These investors are businessmen, so what can we expect. (Key Informant \# 3)

Both the men's and women's FGDs revealed increasing land scarcity driven by the influx of migrant workers. According to an opinion leader in the group, the land shortages forced about $32 \%$ of men to search for land in other villages like Mchombe, Mngeta, and Mbingu to grow food crops. One elder interviewed stated:

Now, I have borrowed money to lease a small plot in another village to grow food crops to feed these children [pointing at five children sitting in front of the door]. We leave these small kids at home because we have to walk three hours to the farm. My wife is always worried because she thinks something bad can happen to them while we are away.

(Interviewee \# MK 24)

Farmers also faced a significant challenge in obtaining water for farming. Because the investor had blocked the road to the main river, households had limited access to water and had to travel long distances searching for water. Most farmers (94\%) relied exclusively on the river as a water source for their farms during the dry season. Some respondents also believed that the runoff from the investor's farm had contaminated the river's tributaries. A few fishermen complained of the declining fish population in the river. As one explained, 
When we go fishing these days, all we find are dead fishes floating on the river, and we wonder why, but it was not like this at first. Now we come home empty-handed, and my wife cannot cook a delicious meal because we do not have fish. My children like fish very much. (Interviewee \# MK 88)

The forests and pasture are critical to all Mkangawalo residents. Almost all respondents $(97 \%)$ relied on forest resources such as fruits, nuts, seeds, roots, and leaves during food scarcity. The FGD revealed that the village obtains traditional medicines, fuelwood, and building materials from the forest. They expressed grievances stemming from the clearance of the forest for the LaSLA project without consulting them first. Some FGD participants expressed anger and resented the investor for encroaching on the forest and bringing hardship to the village. The female participants referred to the increased burden due to an additional 7-12 km for each trip fetching firewood, which is traditionally the responsibility of women. Making such trips is particularly strenuous during the rainy season when it is hard to find any drier firewood. The reduction in access to grazing land also exacerbated household insecurities. Hostility appeared to develop between the villagers and the investor. As one woman expressed,

How can they [referring to the investor and the local government] expect us to survive with no land and no water. Even my goats and sheep have no place to graze. We just do not know what we will do or where life will take us. Two of my children are sick; they need to eat, but we do not have food. (Interviewee \# MK47)

\section{Financial capital}

The findings show that households in the affected and unaffected villages are statistically similar in terms of their off-farm income, savings, and access to loans (Table 2). However, compared to the unaffected village, the affected village's access to loans improved slightly (13\%). Still, their savings and off-farm income declined by $8.15 \%$ and $8.33 \%$, respectively, although these declines were statistically insignificant. More importantly, their farm income declined by $21.18 \%$. Households gave several reasons for these declines. First, the displacement and loss of access to communal pasture forced them to sell off their livestock, resulting in reduced income. Particularly for women, milking cattle and selling dairy products are vital incomemaking activities. These events compelled women to work as day laborers for the investor, typically getting paid less (TSH $9502.53 \approx$ US\$4.11) and working long hours under unsafe conditions as compared to men.

Second, contract farmers in both FGDs said they felt locked into working for the investor because of the advance payment and compulsory deduction for savings. According to the farmers, the investor reached an agreement with them to purchase their rice, provided the rice meets the required standards. They complained that the investor breached the arrangement and refused to buy their rice as initially agreed. All farmers conveyed discontent with the contract farming's rigidity, claiming that the investor did not allow engaging in other off-farm activities like petty trading and the sale of firewood, charcoal, local food, and drinks to diversify their income. One contract farmer explained,

I used to go to nearby towns to do casual labor in construction and also supplement our expenses by raising poultry, but I have lost all my livestock because the investor was very demanding. I regret joining the contract farming, and I plan to quit because I am not earning enough. I cannot only depend on this job alone. (Interviewee \# MK 09)

Third, compensation was promised to affected households, although it is yet to materialize. During all of the FGDs, it was established that those displaced did not receive any form of compensation. Participants mentioned that they were expecting to receive direct monetary compensation from either the investor or the government for losing their farmlands. In addition, for the past five consecutive years, the investor had failed to make an annual payment to the village development fund of TSH 50,000,000 (US $\$ 22,800$ ).

Nevertheless, some participants noted the 
investor offered loans, which helped them purchase farming equipment to support their livelihoods and children's education. Yet, the investor denied those seeking loans who did not have collateral security. Some households $(17 \%)$ could not afford farming inputs to increase their crop yield. When asked about LaSLA's contribution to villager's financial capital, the TIC officer said,

Tanzania has to catch up with the rest of the world. LaSLA provides a great opportunity to do that. Smallholders support the country, but we [referring to the government] must bring in commercial farming to create more opportunities. This is why we have created a conducive investment climate. We provide potential investors with various tax breaks; we have abundant water, affordable land, and an efficient investment process.

\section{Human capital}

There are claims that LaSLA develops human capital, especially in rural areas. Thus, I investigated the extent to which the LaSLA project has affected households' health, education, training, and skills. The results (Table 2) show that both the study and control village are statistically similar in terms of their health, education, and skills, except for training. However, compared to the control village (Chita), households' health and training opportunities in the affected village (Mkangawalo) deteriorated by $15.0 \%$ and $11.9 \%$, respectively. A few factors account for this. First, tenure changes resulting from the LaSLA project altered household labor allocation, which, in turn, caused the physical and mental health of women, particularly, to deteriorate due to their increased workload. In the women's FGD, they described how the reduction in the consumption of meat and milk products due to decreased livestock numbers had affected their ability to produce breastmilk for their babies. One woman commented,

those days [referring to before the LaSLA project], my family would kill a fat cow, share with other households, and sell some for money. I used to milk the cows every day, and we ate healthy and nutritious foods. We have to look good for our husbands, you know! But now, we only eat meat occasionally and have to buy milk sometimes. Life is getting harder and harder each day.

Second, both the household interviews and FGDs pointed to declining health owing to the intense workload and hazardous working conditions on the investor farm. Some female-headed households stated that the displacement had overwhelmed them with responsibilities. One participant described a range of tasks in a typical day. They wake up at dawn to fetch firewood, engage in petty trade for additional income before heading to the investor's farm to work longer hours in the sun, and then go fishing at night, a chore usually reserved for men. The household interviews revealed that some female laborers were regularly exposed to pesticides while mixing, loading, and cleaning the pesticide equipment. Approximately $7 \%$ of respondents complained of stinging eyes, rashes, blisters, and dizziness after working on the investor's farm. During the women's FGD, a pregnant woman stood up and said:

Look at my hands and legs [showing it to the group], my skin has changed, and people continue to ask me why. Now, I always cover my hands and legs before I go out, even to my neighbor's house.

During the key informant interview, the HAKIARDHI officer cited a lack of adequate environmental and social impact assessment of the LaSLA project and weak monitoring and enforcement of labor rights and health (safety) standards by the Tanzania government as reasons for health problems in the affected village. I did not find any evidence of training or transfer of knowledge from the investor to the people. However, the investor's representative explained that the technologies they use are beyond the villagers' knowledge and capabilities. The village chairperson commented on the decline in education, saying,

Because some parents now have to farm outside the village and leave their children unsupervised, the children become truant from 
school and work as casual laborers for the investor. (Interviewee \# MK 75)

\section{Social capital}

I examined the potential impacts of LaSLA on social capital, including social networks, trust, quality of relationships, and access to external services. The results (Table 2 ) show that compared to Chita, Mkangawalo's social networks and trust within the village deteriorated significantly, by $26.97 \%$ and $20.11 \%$, respectively. Similarly, relationships declined slightly by $9.55 \%$. The FGD revealed escalating disputes and tension between villagers and the investor over forest encroachment. Some participants were threatened with arrest by the local government; hence, they remained quiet. It was apparent that trust and reciprocity among households had deteriorated because of different opinions about the investor. Some female participants accused the migrants of fighting with their husbands over laborer jobs. One woman expressed her concern:

Right now, we cannot depend on and trust each other like we used to do some time ago. We do not share our food and drinks because of these migrants [pointing at the investor's site]. I am even afraid that something will happen to me one day, and no one will try to help. (Interviewee \# MK 44)

The household interviews revealed there was no meaningful consultation and involvement of the village in the project negotiation. Approximately $75 \%$ of households were unaware the government had given their land to the investor until he arrived with bulldozers to clear the land. Most farmers expressed strong resentment for being coerced and intimidated by the district authorities to harvest their crops and leave the land. When asked during the key informant interview, the district officers stated that they were acting under the central government's authority to support the investor. Some households expressed anger and distrust in the village leadership about the gender imbalance in decision-making on land tenure. The participants in the women's FGD expressed a deep concern for breaking up their families due to outmigration.
Some also mentioned that they suffer significant separation distress, seeing their husbands migrate away in search of employment and never return.

Moreover, farming in other villages meant that households had little time to return to their village for assembly meetings, social gatherings, and ceremonies. Additionally, households expressed concern about the influx of migrants to the village, stating that young women regularly encounter sexual harassment, and teenage pregnancy was increasing. A mother of two children said,

Sometimes when my husband goes in search of a job, I have no option than to leave these children [pointing at Mposi (5-year boy), Haki (4-year boy), and Mwamba (2-year girl] here alone to go to the farm to bring foodstuffs. If not, we will sleep with an empty stomach that day. (Interviewee \# MK 51)

\section{Physical capital}

A potential benefit of LaSLA is the development of rural infrastructure. Thus, I investigated how LaSLA has shaped farmers' access to irrigation schemes, health facilities, farming inputs, and roads. The results indicate that Mkangawalo and Chita are similar in terms of access to irrigation schemes, health facilities, and livestock raising. However, Mkangawalo households reported a statistically significant decline of $36.79 \%$ in access to roads and transportation. Findings regarding irrigation indicated that, although households reported a decrease in access to water, most contract farmers had access to water throughout the year because of the investor's irrigation system that supplied water to their farms. All households agreed that the investor had built a health clinic, making it easier to access health services rather than traveling about $98 \mathrm{~km}$ (61 mi) to Ifakara, the district capital.

Again, households agreed that the improvement in their access to farming inputs was because they could easily purchase farming equipment and inputs at a much lower price from the investor. During the study, field observation confirmed the decline in access to roads and transportation in Mkangawalo because of overuse. During the rainy season, the roads to various market centers become flooded and impassable, forcing farmers to leave 
their high-value perishable crops on the farm to rot. Although the investor has promised to improve the feeder roads linking Mkangawalo to the main road, this has yet to happen. However, the villagers noted that the investor contributed bags of cement and school desks to support the village primary school's construction.

\section{Discussion}

The SLA allows for the evaluation of LaSLA's effects on rural livelihoods. It helps us understand how the external environment-both the natural environment and the policy and institutional context-affects household livelihood systems (assets, strategies, and outcomes). After comparing Mkangawalo and Chita, the results reveal that the LaSLA project, overall, degraded Mkangawalo households' livelihoods, making them insecure and vulnerable to poverty. When considering vulnerability, we can acknowledge that LaSLA acted as an external shock and stress that affected Mkangawalo's livelihood assets. The LaSLA project caused principal changes in household assets through displacement, relocation, and reduction in land holdings, facilitated by GoT. This is a typical example of how disabling policies and institutions (i.e., transforming structures and processes) can produce adverse livelihood outcomes for rural households by limiting their access to vital resources. Additionally, displacing people with inadequate or no compensation constitutes a violation of fundamental human rights (Künnemann \& Suárez, 2013; Wisborg, 2013). This act goes against Article 10 of the United Nations Declaration on the Rights of Indigenous Peoples (UNDRIP), which states,

Indigenous peoples shall not be forcibly removed from their lands or territories. No relocation shall take place without the free, prior and informed consent of the indigenous peoples concerned and after agreement on just and fair compensation and, where possible, with the option of return. (United Nations, 2008, p. 6)

Regassa et al. (2019) indicate that the politics of coercive sedentarization legitimizes pastoralist communities' eviction from grazing land to make way for corporate investors in Ethiopia. Similarly, Gironde and Golay (2015) report how government policies and regulations usually favor investors and violate local communities' human rights — the right to access land and water. This literature confirms the study's findings regarding how GoT offers incentives and relaxes investment policies to attract investors. Thus, it is not surprising to find weak monitoring and poor enforcement of safety and health standards on investors' farms in Tanzania. In Mkangawalo, households traveled long distances for water, and the infertility of the relocated land affected their farm outputs. Hajjar et al. (2020) have reported similar results in western Ethiopia. According to Breu et al. (2016), access to water is now recognized as a prerequisite for poverty reduction because it is a crucial production asset. In this line of thinking, Allan (2012) has argued for institutional reforms that shift away from a top-down water management approach to a bottom-up approach in LaSLA deals.

Both government and private organizations institute policies and legislations that affect the financial capital of households. The shocks described above compelled people in the study area to work as laborers for the investor to earn a living. Whereas LaSLA advocates hold an optimistic view of employment opportunities, my findings reveal numerous negative consequences. The LaSLA project shifted households' livelihood strategies, transforming them from being mostly self-sufficient smallholders to being dependent on the investor. Mollett (2016) and Oram (2014) note that it is almost impossible for governments and investors to pursue LaSLA without adversely affecting the local population's market shares, incomes, or jobs. In Mkangawalo, I found that:

(1) the investor paid low wages and locked households into the contract farming scheme via advance payment and compulsory deduction for savings,

(2) the investor failed to purchase the rice the contact farmers produced after reaching an agreement with them, and

(3) the rigidity of the contract farming prevented households from growing other crops to improve their food security and 
from engaging in different livelihood strategies (off-farm activities) to diversify their income.

These results show how weak institutionsGoT's lack of monitoring and enforcement of agriculture investment laws-puts households' financial security in investors' hands. Smalley and Corbera (2012) have concluded that investors have used households as cheap labor sources in Kenya's Tana Delta, paying them substantially low wages for long working hours. As in Mkangawalo, meager wages put households on the bottom rung of the rural poverty ladder. On the other hand, in some parts of SSA, research indicates that contract farming plays a crucial role in integrating smallholders into agribusiness chains, increasing their income and local spending (Oya, 2012).

The debate on the potential of LaSLA to improve human and physical capital in developing countries through infrastructure and training is still ongoing. Pesticide poisoning is a particularly prevalent threat in SSA. Costantino (2016) claims that laborers on investors' farms have higher risks of health problems due to chemical exposure and limited recourse to compensation. Like the study's findings, the same story of farmers' exposure to pesticides resulting in Acute Pesticide Poisoning (APP) has been recorded in several villages in the Arusha region of Tanzania (Lekei et al., 2014). In the study area, farmers' lack of knowledge in handling pesticides aggravated these risks. Li (2011) provides examples of cases where investors bring along labor from their home countries, limiting employment opportunities and skill development of the local population. Similarly, Arora and Rada (2017) reveal that increasing labor burdens on women has negatively affected their physical and mental health as well as their farms' productivity.

There is no question that access to certain types of infrastructure tremendously improves livelihood strategies and outcomes. In Mkangawalo, the lack of access to all-weather roads prevented households from transporting their produce to market centers, leaving them to rot on the farm. The investor promised to improve and build roads, but this is yet to materialize. The same story of broken promises is frequently cited in Tanzania and across SSA (Byerlee et al., 2011). The issue of broken promises and investor failure to adhere to the LaSLA contract raises concerns about SSA governments' capacity to negotiate better deals or even to enforce existing agreements.

LaSLA engages governments, investors, and locals and usually influences institutional structures and social processes involving power relations and decision-making. Meaningful involvement of locals in LaSLA negotiation and implementation can prevent adverse livelihood outcomes like forced eviction. In Mkangawalo, the lack of household involvement in the planning and implementation of the LaSLA project led to disputes and disapproval. More importantly, households' lack of formal land titles facilitated the appropriation of their land. Studies indicate that weak land tenure underlies smallholders' displacement in rural Africa (Anseeuw et al., 2012). Again, research shows that local resistance, conflicts, and violence are not exceptions but are rather systemic features of LaSLA deals that lack locals' approval (Gingembre, 2015; Hall et al., 2015). Furthermore, several studies have documented the negative impacts of LaSLA on trust and reciprocity relationships that serve as informal safety nets for the rural poor. Rivera et al. (2019) and Johny et al. (2017) have indicated that the disruption of intravillage social networks negatively affects household income diversification strategies. My findings reveal that the lack of land and employment opportunities prompted Mkangawalo men to leave the village searching for jobs. This outmigration of males broke up families and severely affected households' social capital.

A comment about the potential limitations of this study and future directions for research are in order. First, although the study controlled for demographic effects, personality can influence respondents' perceptions of impact. Second, retrospective data quality is often questionable as it typically suffers from recall bias and lost intraperiod variation. Nevertheless, this should be equally true in both the affected and control villages. The study's use of various data sources helps address the inherent weaknesses associated with retrospective data. Third, the study may only be representative of Tanzania and thus not 
generalizable. However, the findings may be valid beyond the Tanzanian context because the current realities of rural households in Tanzania are everyday experiences across SSA and other parts of the world.

\section{Conclusion}

The recent interest in farmlands, especially in SSA, offers an opportunity to shape old debates with new evidence and address some empirical blind spots that researchers have overlooked in the literature. I have described two competing perspectives on LaSLA as a practice: one that considers LaSLA as a development opportunity, and one that considers LaSLA a threat to development. Whereas advocates argue the need for LaSLA to meet development goals, critics view LaSLA as ruthless exploitation of the poor and reminiscent of colonialism in SSA. Given this context, I evaluated the impacts of the Kilombero Plantation Limited project on the livelihoods of Mkangawalo in the Kilombero district of Tanzania.

The analyses yielded several significant results. First, I find that LaSLA acts as an external force that negatively impacted households' livelihood assets. Households in the affected village have suffered losses in various livelihood capital, including access to land, water, forest, pasture, farm income, and training. Second, the policy and institutional context disadvantaged households and further worsened their access to vital resources needed to escape poverty. Third, to compensate for the decline in livelihood assets, households employed different strategies such as leaving the village and searching for employment elsewhere. Fourth, LaSLA negatively affected households' livelihood outcomes, including reduced income, food security, trust, and social networks. In Mkangawalo, displacement, lack of access to different capital assets, low wages, limited employment, lack of compensation, lack of involvement of local people, and the investor's rigid contract farming policies prevented the positive spillovers from LaSLA.

Under the present conditions, the risks outweigh the benefits of LaSLA in Tanzania. LaSLA in the case study area is exacerbating already precarious livelihoods. Nonetheless, there are potential benefits should the Tanzanian government implement LaSLA carefully. In the end, the critical question is how can we address the risks associated with LaSLA projects and promote their potential benefits. LaSLA outcomes are highly variable, contextspecific, and dependent on factors that are not always fully explored in research. These conclusions affirm the need for more nuanced, contextspecific analyses of LaSLA that consider land tenure security, access to capital, and local involvement in LaSLA processes. This study opens new doors for public policy and investment guidelines for national governments on the critical role of LaSLA in meeting development priorities. Currently, the dominant policy vision for agriculture in SSA is to transition from smallholder to modern LaSLA farms. Future research can investigate how this can happen. I put forward the following policy recommendations for consideration by Tanzania and SSA countries.

(1) LaSLA Business Model: Governments should carefully screen and scrutinize LaSLA deals, ensuring that investor business models align with the local population's long-term vision. Rigid contact farming arrangements without regard to livelihood diversification should be discouraged. LaSLA is causing family separation and putting children and teenage girls at risk due to males' outmigration searching for employment. Public policies should strengthen customary land tenure to ensure households' access to land. This also necessitates that policymakers and investors rethink LaSLA and facilitate greater crop diversity within the local economy to improve household food security.

\section{(2) Environmental and Social Impact Assess-} ments (ESIA): It is critical to conduct a comprehensive ESIA and monitor whether investors follow investment laws or seek to do the bare minimum. An independent body should approve the ESIA before LaSLA operations begin. Such a body should, for example, consider labor and working conditions, ecosystem conservation, health and safety, resettlement, and compensation (Chiarelli et al., 2021; D'Odorico et al., 2017). 
(3) Principle of Free, Prior, and Informed Consent (FPIC): Governments should adhere to the normative framework of free, prior, and informed consent (FPIC) recognized in the United Nations' Declaration on the Rights of Indigenous Peoples (UNDRIP) and embedded within the universal right to self-determination. Here, the government should work with local people and build their capacity to negotiate the conditions for implementing and monitoring contract farming.

(4) Engagement with Communities: There should be meaningful involvement of locals in LaSLA negotiations to represent their interests adequately. This requires that negotiations be transparent, inclusive, and accessible to all. Doing this will provide local people opportunities (e.g., through open forums) to offer feedback and suggestions throughout the negotiations to address various concerns before a LaSLA project is approved.

\section{(5) Monitoring and Enforcement of LaSLA} Contracts: NGOs, civil organizations, and governments should hold investors accountable for breaches of human rights, environmental responsibilities, and promises to the local people. This is only possible if there are clearly defined, formal procedures by which governments and locals can hold investors accountable to their obligations.

(6) Displacement and Compensations: Governments should explore all feasible alternatives to avoid the arbitrary eviction of locals altogether. Eviction leads to violations of economic, social, civil, and political rights, with particularly harsh consequences for women and children. Where displacement is inevitable, the government should provide adequate compensation to victims and promote other livelihood activities to enable displaced communities to earn an income.

\section{Acknowledgments}

The author thanks Saddick Lihinda (research assistant), Professor Ann Kinzig and Prof. Rimjhim Aggarwal (Arizona State University), Professor Damian Gabagambi (Sokoine University of Agriculture, Tanzania), and Sophie Brown (Ph.D. student, SUNY ESF) for their comments on drafts of this paper.

\section{References}

Allan, J. A. (2012). Handbook of land and water grabs in Africa: Foreign direct investment and food and water security. Routledge. https://doi.org/10.4324/9780203110942

Anseeuw, W., Alden Wily, L., Cotula, L., \& Taylor, M. (2012). Land rights and the rush for land: Findings of the global commercial pressures on land research project. International Land Coalition. https://agritrop.cirad.fr/564981/

Anseeuw, W., Boche, M., Breu, T., Giger, M., Lay, J., Messerli, P., \& Nolte, K. (2013). Transnational land deals for agriculture in the global south: Analytical report based on the Land Matrix database. Centre for Development and Environment (CDE). https://boris.unibe.ch/id/eprint/17594

Arora, D., \& Rada, C. (2017). A gendered model of the peasant household: Time poverty and farm production in rural Mozambique. Feminist Economics, 23(2), 93-119. https://doi.org/10.1080/13545701.2016.1220676

Atuoye, K. N., Luginaah, I., Hambati, H., \& Campbell, G. (2021). Who are the losers? Gendered-migration, climate change, and the impact of large-scale land acquisitions on food security in coastal Tanzania. Land Use Policy, 101, Article 105154. https://doi.org/10.1016/j.landusepol.2020.105154

Baumgartner, P., von Braun, J., Abebaw, D., \& Müller, M. (2015). Impacts of large-scale land investments on income, prices, and employment: Empirical analyses in Ethiopia. World Development, 72, 175-190. https://doi.org/10.1016/j.worlddev.2015.02.017

Bourdieu, P., Coleman, J. S., \& Coleman, Z. W. (2019). Social theory for a changing society. Routledge. https://doi.org/10.4324/9780429306440 
Breu, T., Bader, C., Messerli, P., Heinimann, A., Rist, S., \& Eckert, S. (2016). Large-scale land acquisition and its effects on the water balance in investor and host countries. PLOS ONE, 11(3), e0150901. https://doi.org/10.1371/journal.pone.0150901

Byerlee, D., \& Deininger, K. (2013). The rise of large farms in land-abundant countries: Do they have a Future? In S. T. Holden, K. Otsuka, \& K. Deininger (Eds.), Land tenure reform in Asia and Africa: Assessing impacts on poverty and natural resource management (pp. 333-353). Palgrave Macmillan UK. https://doi.org/10.1057/9781137343819_14

Byerlee, D., Deininger, K., Lindsay, J., Norton, A., Selod, H., \& Stickler, M. (2011). Rising global interest in farmland: Can it yield sustainable and equitable benefits? 'The World Bank. https://doi.org/10.1596/978-0-8213-8591-3

Chambers, R. (2011). Sustainable livelihood thinking: An approach to poverty, environment, and development. Institute of Development Studies (UK). https://opendocs.ids.ac.uk/opendocs/handle/20.500.12413/87

Chambers, R., \& Conway, G. (1992). Sustainable rural liveliboods: Practical concepts for the 21st century. Institute of Development Studies (UK). https://opendocs.ids.ac.uk/opendocs/handle/20.500.12413/775

Chan, D., Schmitt, N., Sacco, J. M., \& DeShon, R. P. (1998). Understanding pretest and posttest reactions to cognitive ability and personality tests. Journal of Applied Psychology, 83(3), 471-485. https://doi.org/10.1037/0021-9010.83.3.471

Chiarelli, D. D., D’Odorico, P., Davis, K. F., Rosso, R., \& Rulli, M. C. (2021). Large-scale land acquisition as a potential driver of slope instability. Land Degradation \& Development, 32(4), 1773-1785. https://doi.org/10.1002/ldr.3826

Costantino, A. (2016). The dark side of the boom: Land grabbing independent countries in the twenty-first century. International Critical Thought, 6(1), 79-100. https://doi.org/10.1080/21598282.2016.1142386

Cotula, L. (2012). The international political economy of the global land rush: A critical appraisal of trends, scale, geography, and drivers. The Journal of Peasant Studies, 39(3-4), 649-680. https://doi.org/10.1080/03066150.2012.674940

Dell'Angelo, J., D’Odorico, P., Rulli, M. C., \& Marchand, P. (2017). The tragedy of the grabbed commons: Coercion and dispossession in the global land rush. World Development, 92, 1-12. https://doi.org/10.1016/j.worlddev.2016.11.005

Department for International Development [DfID]. (1999). Sustainable livelihoods guidance sheets. Retrieved from the Emergency Nutrition Network (ENN) website: https://www.ennonline.net/dfidsustainableliving

Dimitrov, D. M., \& Rumrill Jr., P. D. (2003). Pretest-posttest designs and measurement of change. Work, 20(2), $159-165$. https://pubmed.ncbi.nlm.nih.gov/12671209/

D’Odorico, P., Rulli, M. C., Dell'Angelo, J., \& Davis, K. F. (2017). New frontiers of land and water commodification: Socio-environmental controversies of large-scale land acquisitions. Land Degradation \& Development, 28(7), 2234 2244. https://doi.org/10.1002/ldr.2750

Flora, C. B., Flora, J. L., \& Gasteyer, S. P. (2016). Rural communities: Legacy and change. Avalon Publishing.

Gingembre, M. (2015). Resistance or participation? Fighting against corporate land access amid political uncertainty in Madagascar. The Journal of Peasant Studies, 42(3-4), 561-584. https://doi.org/10.1080/03066150.2015.1022867

Gironde, C., \& Golay, C. (2015). Large-scale land acquisitions, livelihoods, and human rights in South-East Asia. Revue international de politique de développement, 6, 275-292. https://doi.org/10.4000/poldev.2065

Gliem, J., \& Gliem, R. (2003). Calculating, interpreting, and reporting Cronbach's alpha reliability coefficient for Likert-type scales. https://scholarworks.iupui.edu/handle/1805/344

Hajjar, R., Ayana, A. N., Rutt, R., Hinde, O., Liao, C., Keene, S., Bandiaky-Badji, S., \& Agrawal, A. (2020). Capital, labor, and gender: The consequences of large-scale land transactions on household labor allocation. The Journal of Peasant Studies, 47(3), 566-588. https://doi.org/10.1080/03066150.2019.1602520

Hall, R., Edelman, M., Borras Jr, S. M., Scoones, I., White, B., \& Wolford, W. (2015). Resistance, acquiescence, or incorporation? An introduction to land grabbing and political reactions 'from below.' The Journal of Peasant Studies, 42(3-4), 467-488. https://doi.org/10.1080/03066150.2015.1036746

Johny, J., Wichmann, B., \& Swallow, B. M. (2017). Characterizing social networks and their effects on income diversification in rural Kerala, India. World Development, 94, 375-392.

https://doi.org/10.1016/j.worlddev.2017.02.002 
Künnemann, R., \& Suárez, S. M. (2013). International human rights and governing land grabbing: A view from global civil society. Globalizations, 10(1), 123-139. https://doi.org/10.1080/14747731.2013.760933

Land Matrix. (2020). Land matrix: The online public database on land deals. https://landmatrix.org/

Lekei, E. E., Ngowi, A. V., \& London, L. (2014). Farmers' knowledge, practices, and injuries associated with pesticide exposure in rural farming villages in Tanzania. BMC Public Health, 14(1), 389. https://doi.org/10.1186/1471-2458-14-389

Li, T. M. (2011). Centering labor in the land grab debate. The Journal of Peasant Studies, 38(2), 281-298. https://doi.org/10.1080/03066150.2011.559009

Liberti, S. (2013). Land grabbing: Journeys in the new colonialism. Verso Books.

Messer, N., \& Townsley, P. (2003). Local institutions and livelihoods: Guidelines for analysis. Rural Development Division, Food \& Agriculture Organization.

Mollett, S. (2016). The power to plunder: Rethinking land grabbing in Latin America. Antipode, 48(2), 412-432. https://doi.org/10.1111/anti.12190

Nkansah-Dwamena, E., \& Raschke, A. B. (2020). Justice and fairness for Mkangawalo people: The case of the Kilombero large-scale land acquisition (Lasla) project in Tanzania. Ethics, Policy \& Environment. Advance online publication. https://doi.org/10.1080/21550085.2020.1848187

Nolte, K., \& Voget-Kleschin, L. (2014). Consultation in large-scale land acquisitions: An evaluation of three cases in Mali. World Development, 64, 654-668. https://doi.org/10.1016/j.worlddev.2014.06.028

O.Nyumba, T., Wilson, K., Derrick, C. J., \& Mukherjee, N. (2018). The use of focus group discussion methodology: Insights from two decades of application in conservation. Methods in Ecology and Evolution, 9(1), $20-32$. https://doi.org/10.1111/2041-210X.12860

Oram, J. (2014). The great land heist: How the world is paving the way for corporate land grabs. ActionAid International.

Oya, C. (2012). Contract farming in sub-Saharan Africa: A survey of approaches, debates, and issues. Journal of Agrarian Change, 12(1), 1-33. https://doi.org/10.1111/i.1471-0366.2011.00337.x

Pedersen, R. H. (2016). Access to land reconsidered: The land grab, polycentric governance, and Tanzania's new wave land reform. Geoforum, 72, 104-113. https://doi.org/10.1016/i.geoforum.2015.12.010

Putman, R. (1993). Making democracy work. Princeton University Press.

Regassa, A., Hizekiel, Y., \& Korf, B. (2019). 'Civilizing' the pastoral frontier: Land grabbing, dispossession and coercive agrarian development in Ethiopia. The Journal of Peasant Studies, 46(5), 935-955. https://doi.org/10.1080/03066150.2017.1420060

Rivera, M., Knickel, K., Díaz-Puente, J. M., \& Afonso, A. (2019). The role of social capital in agricultural and rural development: Lessons learnt from case studies in seven countries. Sociologia Ruralis, 59(1), 66-91. https://doi.org/10.1111/soru.12218

Salverda, T. (2019). Facing criticism: An analysis of (land-based) corporate responses to the large-scale land acquisition countermovement. The Journal of Peasant Studies, 46(5), 1003-1020. https://doi.org/10.1080/03066150.2018.1439930

Scoones, I. (2015). Sustainable livelihoods and rural development (IDS Working Paper 72). Practical Action Publishing. https://doi.org/10.3362/9781780448749

Scoones, I. (1998). Sustainable rural livelihoods: A framework for analysis. Institute of Development Studies. https://www.ids.ac.uk/publications/sustainable-rural-livelihoods-a-framework-for-analysis/

Shete, M., \& Rutten, M. (2015). Impacts of large-scale farming on local communities' food security and income levelsEmpirical evidence from Oromia Region, Ethiopia. Land Use Policy, 47, 282-292. https://doi.org/10.1016/j.landusepol.2015.01.034

Smalley, R., \& Corbera, E. (2012). Large-scale land deals from the inside out: Findings from Kenya's Tana Delta. The Journal of Peasant Studies, 39(3-4), 1039-1075. https://doi.org/10.1080/03066150.2012.686491

Sulle, E. (2017). Social differentiation and the politics of land: Sugar cane outgrowing in Kilombero, Tanzania. Journal of Southern African Studies, 43(3), 517-533. https://doi.org/10.1080/03057070.2016.1215171

Sulle, E., \& Nelson, F. (2009). Biofuels, land access, and rural livelihoods in Tanzania. International Institute for Environment and Development (IIED). https://pubs.iied.org/12560iied 
Tafon, R., \& Saunders, F. (2019). The politics of land grabbing: State and corporate power and the (trans)nationalization of resistance in Cameroon. Journal of Agrarian Change, 19(1), 41-63. https://doi.org/10.1111/joac.12264

Tanzania National Bureau of Statistics. (2018). Tanzania in Figures 2018. National Statistical System (NSS). https:/ / www.nbs.go.tz/index.php/en/tanzania-in-figures/422-tanzania-in-figures-2018

United Nations (2008). United Nations declaration on the rights of indigenous peoples. https://www.un.org/esa/socdev/unpfii/documents/DRIPS_en.pdf

White, B., Borras Jr, S. M., Hall, R., Scoones, I., \& Wolford, W. (2012). The new enclosures: Critical perspectives on corporate land deals. The Journal of Peasant Studies, 39(3-4), 619-647. https://doi.org/10.1080/03066150.2012.691879

Wisborg, P. (2013). Human rights against land grabbing? A reflection on norms, policies, and power. Journal of Agricultural and Environmental Ethics, 26, 1199-1222. https://doi.org/10.1007/s10806-013-9449-8

Yin, R. K. (2017). Case study research and applications: Design and methods. Sage Publications.

Zoomers, A., van Noorloos, F., Otsuki, K., Steel, G., \& van Westen, G. (2017). The rush for land in an urbanizing world: From land grabbing toward developing safe, resilient, and sustainable cities and landscapes. World Development, 92, 242-252. https://doi.org/10.1016/j.worlddev.2016.11.016 